\title{
Complete Remission and Long-term Survival of a Patient with a Diffuse Large B-cell Lymphoma Under Viscum album Extracts After Resistance to R-CHOP: A Case Report
}

\author{
JOHANNES GUTSCH ${ }^{1}$, PAUL G. WERTHMANN ${ }^{2}$, ANDREAS ROSENWALD ${ }^{3}$ and GUNVER S. KIENLE KN $^{2,4}$ \\ ${ }^{1}$ Gemeinschaftskrankenhaus Herdecke, University Hospital of the University of Witten/Herdecke, Herdecke, Germany; \\ ${ }^{2}$ Institute for Applied Epistemology and Medical Methodology, University of Witten/Herdecke, Freiburg, Germany; \\ ${ }^{3}$ Institute of Pathology and Comprehensive Cancer Center Mainfranken, \\ University of Würzburg, Würzburg, Germany; \\ ${ }^{4}$ Center for Complementary Medicine, Institute for Infection Prevention and Hospital Epidemiology, \\ Medical Center, Faculty of Medicine, University of Freiburg, Freiburg, Germany
}

\begin{abstract}
Background: A nodular lymphocyte predominant Hodgkin's lymphoma (NLPHL) is a lymphoproliferative neoplasm with a fair prognosis, but the possibility of a malignant transformation into a diffuse large B-cell lymphoma $(D L B C L)$ is high. DLBCL progresses aggressively. Introduction of rituximab into therapy had led to improved outcomes. The use of Viscum album extracts (VAE) in cancer is established, but their application in lymphoma are rare. Case Presentation: A 65-year-old patient was diagnosed with DLBCL stage IIa with splenomegaly, transformed from a NLPHL, after a 30year history of repeatedly enlarged inguinal lymph nodes. The patient initially rejected chemotherapy. After his tumor pain increased, he accepted the consecutive therapies bendamustine plus vincristine plus prednisolone, trofosfamide, and rituximab plus cyclophosphamide plus hydroxydaunorubicin plus vincristine plus prednisone (R-CHOP), inducing only a slight regression of the splenic lesions. VAE was additionally applied to R-CHOP. Five months after termination of chemotherapy under continued VAE therapy in increasing dosageregression of paraaortal lesions was found. The patient fully recovered under continuous VAE application and is in ongoing complete remission and in a good state of health 17 years after
\end{abstract}

This article is freely accessible online.

Correspondence to: Paul G. Werthmann, Institute for Applied Epistemology and Medical Methodology at the University of Witten/Herdecke, Zechenweg 6, D-79111 Freiburg i. Brsg., Germany. Tel: +49 15771984421, e-mail: paul.werthmann@ifaemm.de

Key Words: Diffuse large B-cell lymphoma, Viscum album, mistletoe, nodular lymphocyte predominant Hodgkin's lymphoma, malignant transformation. the initial diagnosis. Conclusion: As complete remission of lymphoproliferative disorders after VAE treatment has been previously reported, further investigations of VAE in lymphoma seem highly worthwhile.

A nodular lymphocyte predominant Hodgkin's lymphoma (NLPHL) is a lymphoproliferative neoplasm with a fair prognosis, but transformation into a diffuse large B-cell lymphoma (DLBCL) is seen in $7.6 \%$ to $12 \%$ of cases after 10 years (1-3). DLBCL is aggressive when left untreated. Introduction of rituximab into CHOP-therapy (cyclophosphamide, doxorubicin, vincristine, prednisolone) has led to improved outcomes. However, patients with resistance to RCHOP show a median survival of only 0.4 years (4). Huang reported in the Nebraska Lymphoma Study Group 7 patients with simultaneous and 14 patients with secondary transformation into a DLBCL after only one year (range=0.5-24 years); prognosis in these cases was poor with a median overall and disease-free survival of 35 and 11, months respectively (5). Patients with extra nodal lesions have a median survival time of only 16 months under multimodal chemotherapy with or without stem cell transplantation (5). We found no survival data about patients with a malignant transformation from NLPHL to DLBCL with resistance to chemotherapy.

Viscum album extract (VAE) is an aqueous extract derived from European mistletoe, a hemi-parasitic plant growing on different host trees (apple, pine, elm, oak and other trees). Commercial-injectable VAE preparations are available for supportive use in patients with cancer. VAEs are usually applied subcutaneously in an individuallyadapted, dose-increasing schedule; however, intravenous and intratumoral applications, as well as intracavitary instillations, have also been reported (6). VAEs contain mistletoe lectins, viscotoxins, oligo- and polysaccharides, 
flavonoids, triterpene acids, and other pharmacologically active compounds. VAEs - and particularly their lectins are strongly cytotoxic and induce apoptosis and increase cytotoxicity of chemotherapeutic agents $(7,8)$. They can down-regulate a variety of cancer genes involved in tumor progression, reduce cell migration, and interfere with tumor angiogenesis $(9,10)$. VAE and its compounds show strong immune stimulatory effects and neutralize the immune suppressive effects of tumors $(11,12)$. Clinical trials have found an improved quality of life in cancer patients treated with VAE (13); increased survival under VAE treatment has been reported in patients with advanced pancreatic cancer (14). Case reports and case series have documented the regression of different tumor types after application of VAE $(6,15,16)$. Side effects include self-limited dose-dependent local skin reactions, flu-like symptoms, and occasionally allergic or pseudo-allergic reactions. Otherwise, VAE therapy is regarded as safe, even at higher doses (17). Clinical studies on VAE in patients with lymphoma are sparse compared to other tumor entities.

\section{Case Presentation}

A 65-year-old Caucasian male patient had a 30-year history of enlarged inguinal lymph nodes that were repeatedly investigated, only showing activated lymphocytes, reticulocytes, and granulocytes; ultrasound examination showed enlarged nodes in the right inguinal region of 2-6.8 $\mathrm{cm}$. As the patient experienced increasing pain in the right inguinal region, a computed tomography (CT) scan was performed, showing increased nodes up to $9 \times 6.2 \times 5.6 \mathrm{~cm}$ in the right inguinal region as well as iliacal lymphoma enlarged up to $2 \mathrm{~cm}$. Three months later, the patient underwent surgical excision of the right inguinal lesion, which had further increased in size to $11 \times 10 \times 9 \mathrm{~cm}$. Histologically, the lesion showed areas of a NLPHL and areas with features of a DLBCL (Figure 1). In a following CT scan, splenomegaly of $15 \times 13 \times 8 \mathrm{~cm}$ was found with splenic lesions up to $2.5 \times 3.5 \mathrm{~cm}$; nodes were enlarged around the right $\mathrm{A}$. iliaca externa and interna up to $2.5 \mathrm{~cm}$ and paraaortal up to $1.5 \mathrm{~cm}$. The patient was diagnosed with a DLBCL stage II with splenomegaly, without B symptoms. He had a Karnofsky performance index of $70 \%$ (ECOG I) and lactate dehydrogenase (LDH) was elevated to $320 \mathrm{U} / 1$ (0-240) at initial diagnosis (International Prognostic Index (IPI) score 3$)$. He had a normal body weight $(68 \mathrm{~kg}$, height $176 \mathrm{~cm}$ ), and showed no signs of immune suppression. Further investigation showed no involvement of the bone marrow (aspiration biopsy of the sternum and iliac crest); beta-2-microglobulin was elevated to $3.4 \mu \mathrm{g} / \mathrm{ml}$ (1.1-2.4); and he had anemia (hemoglobin $12.9 \mathrm{~g} / \mathrm{dl}$ ).

Curative chemotherapy with R-CHOP with adjunct VAE treatment was proposed to the patient to increase the immune competency, reduce side-effects, and increase quality of life (18-20) and potentially reduce tumor growth $(15,21)$. The patient initially rejected these therapies, but in the following months, he experienced increasing pain in the upper abdomen and agreed to treatment with bendamustine, vincristine, and prednisolone (BOP). However, the treatment was stopped after 2 cycles due to increasing pain and decreased performance status. He accepted a palliative treatment with 3 cycles of Trofosfamide, but the tumor pain in the upper abdomen increased further during this therapy and opiates had to be prescribed. A CT scan showed that the paraaortal lymph nodes had increased to $6 \times 6 \mathrm{~cm}$ and formed around the coeliac trunk and the Arteria mesenterica superior, compressing the retropancreatic vessels; abdominal tumor pain seemed to be caused by this tumor; splenomegaly was $16 \times 13 \times 7 \mathrm{~cm}$ with multiple lesions up to $5 \mathrm{~cm}$ (Figure $2)$. Six cycles of R-CHOP were applied with adjunct treatment with VAE (Figure 2). At the beginning of this therapy, beta-2-microglobulin was in the normal range $(1.5 \mathrm{mg} / \mathrm{l})$, the patient still showed elevated levels of $\mathrm{LDH}$ (363 U/1), anemia (hemoglobin $11.8 \mathrm{~g} / \mathrm{dl}$ ), and low but normal thrombocytes (146 cells/nl) and leukocytes (5.86 cells/nl); during the therapy granulocyte colony-stimulating factor had to be applied due to low leukocytes $(0.8$ cells $/ \mathrm{nl})$. After the sixth cycle, only minor tumor regression was seen (splenomegaly: no change; intrasplenic lesions: slightly regressed, paraaortal nodes: no change, iliacal nodes: partly regressed). No infections or fever occurred during the course of treatment.

The VAE treatment was started with a very low dose of $1 \mathrm{mg}$ as subcutaneous injection 3 times per week concomitant to chemotherapy. The dose was increased 8 months later to $5 \mathrm{mg}$. Further augmentations to $10 \mathrm{mg}, 20 \mathrm{mg}, 30 \mathrm{mg}$, up to $50 \mathrm{mg}$ (reached in December 2009) followed. The therapy was continued until December 2012. In increasing dosage, local selflimiting skin reactions $<3 \mathrm{~cm}$ occurred; no other side effects were reported.

Five months after termination of chemotherapy and during ongoing VAE treatment, regression of the paraaortal lesions to $2 \mathrm{~cm}$ was found. Under continuous VAE application, a complete remission of all lesions was recorded after one year (spleen: $13 \times 8.8 \times 7 \mathrm{~cm}$; intrasplenic tissue: homogenous; paraaortal nodes $<1.9 \mathrm{~cm}$; iliacal nodes $<1.4 \mathrm{~cm}$ ); the anemia, low thrombocytes, and high levels of $\mathrm{LDH}$ normalized within this period, and the patient had no pain and did not require use of analgesics. Subsequent follow-up investigations were performed with ultrasound, clinical examination, and laboratory tests every 3 months for the first 5 years and every 6 months after that. The patient is in ongoing remission and in a good state of health with a Karnofsky performance index of $100 \%$ and a body weight of $70 \mathrm{~kg}, 17$ years after initial diagnose (for details of the course of treatment, see Figure 2). 


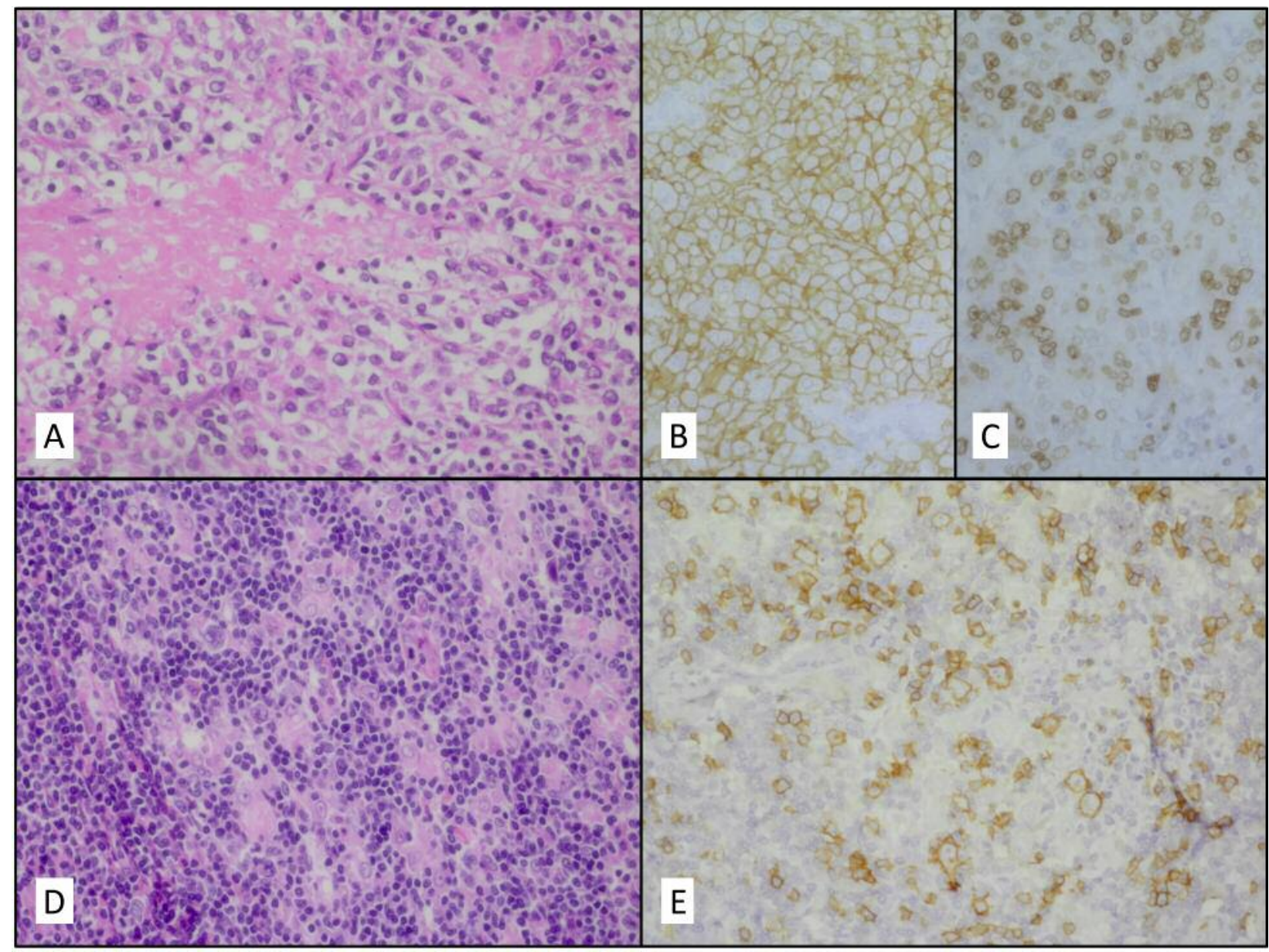

Figure 1. Patient's tumor. Transformation of a NLPHL into a DLBCL. Two different infiltration patterns can be seen within the patient's tumor tissue: there are DLBCL regions $(A-C)$ with a diffuse infiltration of medium- to large-sized blasts, that immunohistochemically show a diffuse reaction to the B cell-associated CD20-antigen; in these regions, there are scarce infiltrations of T-cells or histiocytes. Other regions (D-E) show an NLPHL with a mostly nodular tumor morphology with a diverse background of small activated lymphocytes, histiocytes and activated vessels. A: HE-stain 400x; B: CD20-stain 400x; C: Ki67-stain 400x; D: HE stain 400x; E: CD20 stain 400x. DLBCL: Diffuse large B-cell lymphoma; NLPHL: nodular lymphocyte predominant Hodgkin's lymphoma.

\section{Informed Consent}

Informed consent was received from the patient for the publication of the report. The patient read the submission version of the report and confirmed its content.

\section{Antecedent and Concomitant Therapies}

The patient had Gilbert's syndrome, hypertension, an asymptomatic mitral insufficiency, and cholelithiasis. During chemotherapy, the patient received bisoprolol for hypertension and bromazepam for paroxysmal anxiety attacks with tachycardia. The patient took nutritional supplements during chemotherapy including: selenium, zinc, magnesium, acerola tablets, and iron $14 \mathrm{mg}$ per day. In the follow-up period after chemotherapy, the patient received 10 autohemotherapy treatments with ozone and local ointment application at the spleen containing $0.4 \%$ plumbum. No other anticancer treatment was given after termination of R-CHOP.

\section{Discussion}

In the case presented herein, the patient received palliative therapy with BOP, followed by trofosfamid and 6 cycles of $\mathrm{R}$-CHOP. This treatment induced no tumor response (only slight regression of splenic lesions) and was stopped according to the patient's wishes. During the subsequent year, under sole VAE intervention in increasing dosage, all 


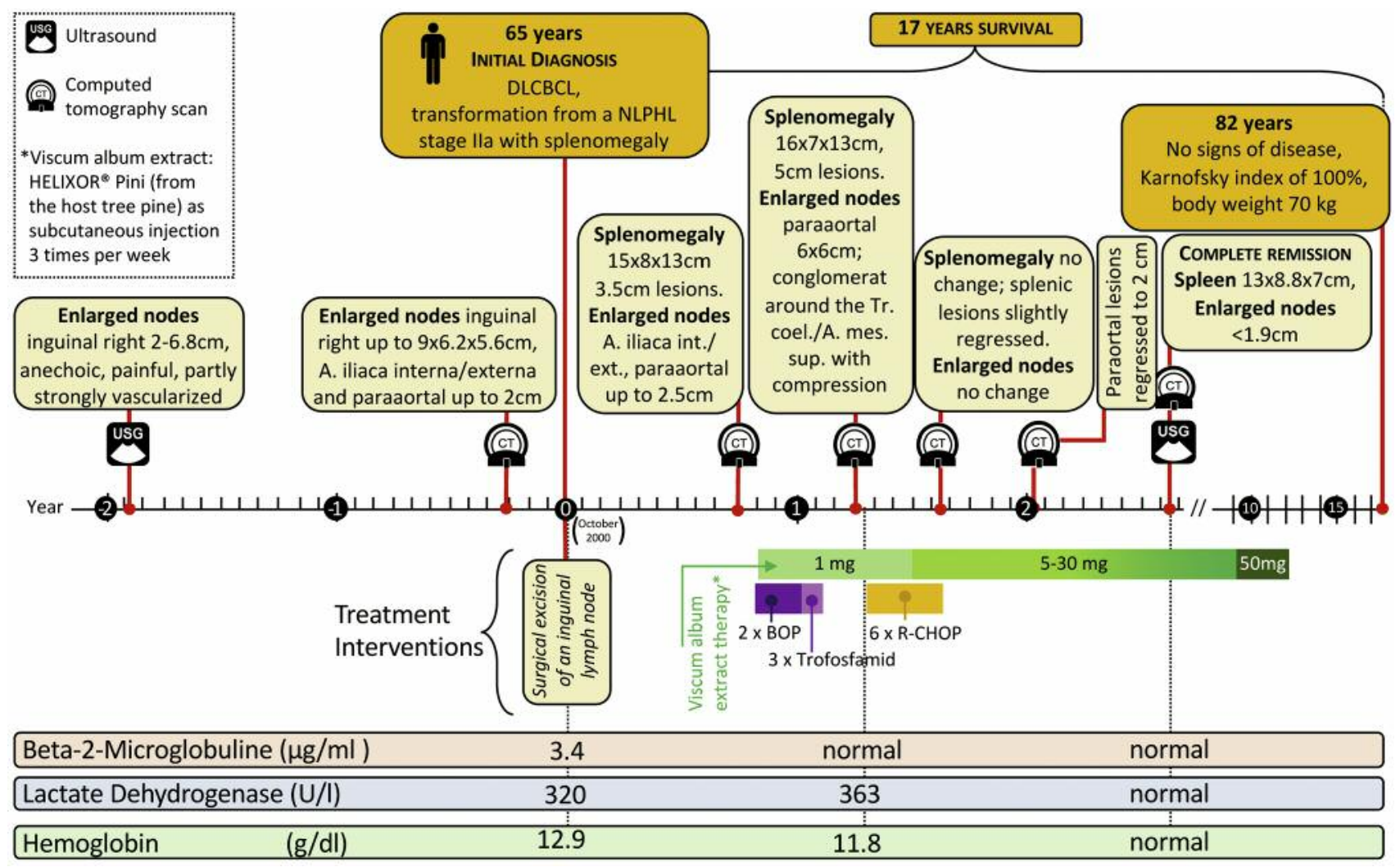

Figure 2. Timeline of the patient and treatment.

lesions of the lymphoma completely regressed. During this period, no other tumor-specific therapy had been applied. In this patient, the malignant transformation from NLPHL to a DLBCL had been confirmed histologically and reconfirmed for publishing this case.

The effects of VAE and its constituents on lymphoma cells have been investigated repeatedly: VAEs have been shown to be antiproliferative, cytotoxic, apoptosis-inducing and cell cycle - arresting $(22,23)$; they induced an increased lymphocyte infiltration of the tumor tissue, reduced neoangiogenesis and metastasis and enhanced survival in murine models (24-26). Additionally, the adoptive application of VAE-stimulated monocytes/macrophages induced tumor inhibition in mice with Ehrlich ascites carcinoma and mammary adenocarcinoma $(27,28)$. In human, smaller studies described remissions of nonHodgkin-lymphoma (29). Three studies investigating safety found no risks of VAE treatment in Hodgkin's lymphoma and non-Hodgkin-lymphoma (30-32). Several case reports described durable tumor remission under VAE in malignant nodular lymphoma $(21,33,34)$ and in cutaneous B-cell lymphoma (15). A complete remission of a pediatric nodal anaplastic large-cell lymphoma with cutaneous lymph proliferation under sole treatment with high-dose VAE was described (16). We therefore presume that VAE also contributed to the successful outcome of our patient.

However, regressions of DLBCL after months or even years after completion of R-CHOP also have been reported; Selenco et al. suggested a cross-priming of cytotoxic T cells to explain this phenomenon - tumor antigens from apoptosis during RCHOP therapy led to an immune reaction with activation of cytotoxic $\mathrm{T}$ cells against the tumor tissue (35). Reports about spontaneous remission of a DLBCL transformed from an NLPHL couldn't be found in the literature. However, there are some cases about spontaneous remission of DLBCL (36). Spontaneous remissions are primarily explained by an induction of cytokines and stimulation of antitumor immune response of the host (36-38). This hypothesis is supported by remission after infections $(36,39,40)$, the remission of MALT lymphomas of the stomach after eradication of Helicobacter pylori $(41,42)$, or remission after reduction of immune suppressive treatment (43-46) or the start of treatment of HIV infection (47). Infiltration with $\mathrm{T}$ lymphocytes has been observed after remission $(37,48,49)$. A role of the tumor 
microenvironment is discussed as remission has been observed after biopsy (36), surgery (50), and injury (51). Remissions of malignant lymphoma have been induced by immunotherapy like active vaccination (immune peptides, DNA sequences, in situ vaccination), $\mathrm{T}$ cell stimulation, and modulation of the microenvironment (52). Taking all these together, lymphoma seems highly immunogenic as has also been seen in responsiveness to immunological treatment approaches as well as to $\operatorname{VAE}(38,52)$.

\section{Conclusion}

Considering the immunogenicity of lymphoma, the immunestimulating effects of VAE, and the course of the patient with resistance to immunochemotherapy and complete remission under increasing VAE therapy, we presume that VAE contributed to the positive outcome in this case. Late response to R-CHOP with induction of immunologic processes might have acted synergistically with the VAE therapy here.

This is only a retrospective report about a single patient, and no conclusion can be drawn from this and correlated to the treatment response of other patients. Therefore, VAE cannot replace current standard treatment for DLBCL. However, this case shows very interesting results regarding safety and possible effectiveness of VAE treatment in DLBCL. Further investigations seem worthwhile regarding this case and the current evidence about VAE use in lymphoma.

\section{Conflicts of Interest}

The Authors declare no conflicts of interest regarding this study.

\section{Acknowledgements}

The Authors are thankful to the "Stiftung Integrative Medizin" for financial support. This case report was prepared following the CARE Guidelines (53).

\section{References}

1 Fuchs M, Eichenauer DA, Nogová L, Diehl V and Engert A: Nodular lymphocyte-predominant Hodgkin lymphoma. Curr Hematol Malig Rep 3: 126-131, 2008.

2 Biasoli I, Stamatoullas A, Meignin V, Delmer A, Reman O, Morschhauser F, Coiffier B, Bosly A, Diviné M and Brice P: Nodular, lymphocyte-predominant Hodgkin lymphoma: A longterm study and analysis of transformation to diffuse large B-cell lymphoma in a cohort of 164 patients from the Adult Lymphoma Study Group. Cancer 116: 631-639, 2010.

3 Kenderian SS, Habermann TM, Macon WR, Ristow KM, Ansell SM, Colgan JP, Johnston PB, Inwards DJ, Markovic SN, Micallef IN, Thompson CA, Porrata LF, Martenson JA, Witzig TE and Nowakowski GS: Large B-cell transformation in nodular lymphocyte-predominant Hodgkin lymphoma: 40-year experience from a single institution. Blood 127: 1960-1966, 2016.
4 Rovira J, Valera A, Colomo L, Setoain X, Rodríguez S, MartínezTrillos A, Giné E, Dlouhy I, Magnano L, Gaya A, Martínez D, Martínez A, Campo E and López-Guillermo A: Prognosis of patients with diffuse large B cell lymphoma not reaching complete response or relapsing after frontline chemotherapy or immunochemotherapy. Ann Hematol 94: 803-812, 2015.

5 Huang JZ, Weisenburger DD, Vose JM, Greiner TC, Aoun P, Chan WC, Lynch JC, Bierman PJ and Armitage JO: Diffuse Large B-cell lymphoma arising in nodular lymphocyte predominant Hodgkin lymphoma: a report of 21 cases from the Nebraska Lymphoma Study Group. Leuk Lymphoma 45: 15511557, 2004

6 Kienle GS and Kiene H: Complementary cancer therapy: a systematic review of prospective clinical trials on anthroposophic mistletoe extracts. Eur J Med Res 12: 103-119, 2007.

7 Beztsinna N, de Matos MBC, Walther J, Heyder C, Hildebrandt E, Leneweit G, Mastrobattista E and Kok RJ: Quantitative analysis of receptor-mediated uptake and pro-apoptotic activity of mistletoe lectin-1 by high content imaging. Sci Rep 8: 2768, 2018.

8 Weissenstein $U$, Kunz $M$, Urech $K$ and Baumgartner $S$ : Interaction of standardized mistletoe (Viscum album) extracts with chemotherapeutic drugs regarding cytostatic and cytotoxic effects in vitro. BMC Complement Altern Med 14: 1, 2014.

9 Podlech O, Harter PN, Mittelbronn M, Pöschel S and Naumann U: Fermented mistletoe extract as a multimodal antitumoral agent in gliomas. Evid Based Complement Alternat Med 2012: 1-15, 2012.

10 Elluru SR, van Huyen J-PD, Delignat S, Prost F, Heudes D, Kazatchkine MD, Friboulet A and Kaveri S: Antiangiogenic properties of viscum album extracts are associated with endothelial cytotoxicity. Anticancer Res 29: 2945-2950, 2009.

11 Kienle GS and Kiene H: Die Mistel in der Onkologie - Fakten und konzeptionelle Grundlagen. Stuttgart, New York, Schattauer Verlag, 2003.

12 Steinborn C, Klemd AM, Sanchez-Campillo A-S, Rieger S, Scheffen M, Sauer B, Garcia-Käufer M, Urech K, Follo M, Ücker A, Kienle GS, Huber R and Gründemann C: Viscum album neutralizes tumor-induced immunosuppression in a human in vitro cell model. Plos One 12: e0181553, 2017.

13 Kienle GS and Kiene H: Influence of Viscum album L (European mistletoe) extracts on quality of life in cancer patients: a systematic review of controlled clinical studies. IntegrCancer Ther 9: 142-157, 2010.

14 Tröger W, Galun D, Reif M, Schumann A, Stanković N and Milićević M: Viscum album [L.] extract therapy in patients with locally advanced or metastatic pancreatic cancer: A randomised clinical trial on overall survival. Eur J Cancer 49: 3788-3797, 2013.

15 Orange M, Lace A, Fonseca MP, von Laue BH, Geider S and Kienle GS: Durable regression of primary cutaneous B-cell lymphoma following fever-inducing mistletoe treatment: two case reports. Glob Adv Health Med 1: 18-25, 2012.

16 Kameda G, Kempf W, Oschlies I, Michael K, Seifert G and Längler A: Nodal anaplastic large-cell lymphoma ALK-1- with CD30+ cutaneous lymphoproliferation treated with mistletoe: spontaneous remission or treatment response? Klin Pädiatr 223: 364-367, 2011.

17 Kienle GS, Grugel R and Kiene H: Safety of higher dosages of Viscum album L. in animals and humans - systematic review of immune changes and safety parameters. BMC Complement Altern Med 11: 72, 2011. 
18 Troger W, Galun D, Reif M, Schumann A, Stankovic N and Milicevic M: Quality of life of patients with advanced pancreatic cancer during treatment with mistletoe: a randomized controlled trial. Dtsch Arztebl Int 111: 493-502, 33, 2014.

19 Piao BK, Wang YX, Xie GR, Mansmann U, Matthes H, Beuth J and Lin HS: Impact of complementary mistletoe extract treatment on quality of life in breast, ovarian and non-small cell lung cancer patients a prospective randomized controlled clinical trial. Anticancer Res 24: 303-310, 2004.

20 Auerbach L, Vaclavik-Fleck I, Dostal V and Kubista E: Significant higher level of activated NK-cells in patients with breast cancer receiving a Viscum album (mistletoe) extract during chemotherapy. Focus Altern Complement Ther 9: 3-4, 2010.

21 Kuehn JJ: [Favorable long-term outcome with mistletoe therapy in a patient with centroblastic-centrocytic non-Hodgkin lymphoma]. Dtsch Med Wochenschr 124: 1414-1418, 1999.

22 Kovacs E, Link $S$ and Toffol-Schmidt U: Comparison of VISCUM ALBUM QuFrF extract with vincristine in an in vitro model of human B cell lymphoma. Drug Res 58: 592-597, 2008.

23 Kuttan G, Vasudevan D and Kuttan R: Tumor reducing activity of an isolated active ingredient from mistletoe extract and its possible mechanism of action. J Exp Clin Cancer Res 11: 7-12, 1992.

24 Kuttan G, Vasudevan D and Kuttan R: Effect of a preparation from Viscum album on tumor development in vitro and in mice. J Ethnopharmacol 29: 35-41, 1990.

25 Braun J, Ko H, Schierholz J, Weir D, Blackwell C and Beuth J: Application of standardized mistletoe extracts augment immune response and down regulates metastatic organ colonization in murine models. Cancer Lett 170: 25-31, 2001.

26 Pryme IF, Bardocz S, Pusztai A and Ewen S: Dietary mistletoe lectin supplementation and reduced growth of a murine nonHodgkin lymphoma. Histol Histopathol 17: 261-271, 2002.

27 Klett C and Anderer F: Activation of natural killer cell cytotoxicity of human blood monocytes by a low molecular weight component from viscum album extract. Arzneimittelforschung 39: 1580-1585, 1989.

28 Kuttan G: Tumoricidal activity of mouse peritoneal macrophages treated with Viscum album extract. Immunol Invest 22: 431-440, 1993.

29 Kuehn JJ: Treatment responses to viscum album pini (iscador ${ }^{\circledR}$ P) in non-hodgkin's lymphoma exploring a new therapeutic route. Medicina (Mex) 67: 107-114, 2007.

30 Stumpf C, Rosenberger A, Rieger S, Tröger W and Schietzel M: [Mistletoe extracts in the therapy of malignant, hematological and lymphatic diseases - a monocentric, retrospective analysis over 16 years]. Forsch Komplementärmedizin Klass Naturheilkunde Res Complement Nat Class Med 7: 139-146, 2000.

31 Wagner R: Eine Praxisbeobachtung 1993-1996. IscadorInformationen Ver Für Krebsforsch E V Ostfildern 4: 1-42, 1996.

32 Gutsch J, Rieger S and Schlodder D: Observational study on treatment of lymphocytic Non Hodgkin's Lymphoma (CLL) with Viscum album products Helixor P or A: Clinical course and safety. Phytomedicine Int J Phytother Phytopharm 18: S10-S10, 2011.

33 Goyert A: Niedrig dosierte Misteltherapie bei niedrig malignem Non-Hodgkin-Lymphom - Erfahrungsbericht. In: Grundlagen der Misteltherapie: aktueller Stand der Forschung und klinische Anwendung; 5. - 7. Oktober 1995 in Homburg-Schwarenacker. Scheer R (ed.). Stuttgart, Hippokrates-Verl, pp. 362-365, 1996.
34 Kuehn JJ: Mistletoe Therapy in Malignant Lymphomas. In: Fortschritte in der Misteltherapie: aktueller Stand der Forschung und klinische Anwendung;Otzenhausen 20.-22. November 2003. Scheer R (ed.). Essen, KVC-Verl, pp. 477-489, 2005.

35 Selenko N, Majdic O, Jäger U, Sillaber C, Stöckl J and Knapp W: Cross-priming of cytotoxic T cells promoted by apoptosisinducing tumor cell reactive antibodies? J Clin Immunol 22: 124-130, 2002.

36 Buckner TW, Dunphy C, Fedoriw YD, van Deventer HW, Foster MC, Richards KL and Park SI: Complete Spontaneous Remission of Diffuse Large B-Cell Lymphoma of the Maxillary Sinus After Concurrent Infections. Clin Lymphoma Myeloma Leuk 12: 455-458, 2012.

37 Alcántara-González J, González-García C, Fernández-Guarino $\mathrm{M}$ and Jaén-Olasolo P: Spontaneous regression of primary diffuse large B-cell lymphoma, leg type. Actas DermoSifiliográficas Engl Ed 105: 78-83, 2014.

38 Abe R, Ogawa K, Maruyama Y, Nakamura N and Abe M: Spontaneous regression of diffuse large B-cell lymphoma harbouring epstein-barr virus: a case report and review of the literature. J Clin Exp Hematop 47: 23-26, 2007.

39 Tamura J, Jinbo T, Take H, Matsushima T, Sawamura M, Murukami H, Kubota K, Naruse T and Tsuchiya J: Spontaneous regression in B cell, diffuse large cell type non-Hodgkin's lymphoma. Acta Haematol 90: 46-47, 1993.

40 Wiernik PH: Spontaneous regression of hematologic cancers. Natl Cancer Inst Monogr 44: 35-38, 1976.

41 Cavanna L, Pagani R, Seghini P, Zangrandi A and Paties C: High grade B-cell gastric lymphoma with complete pathologic remission after eradication of helicobacter pylori infection: Report of a case and review of the literature. World J Surg Oncol 6: 35, 2008.

42 Watari J, Saitoh Y, Fujiya M, Nakamura K, Inaba Y, Okamoto $\mathrm{K}$, Tanabe $\mathrm{H}$, Yasuda A, Miyokawa $\mathrm{N}$ and Kohgo $\mathrm{Y}$ : Spontaneous remission of primary diffuse large B-cell gastric lymphoma. J Gastroenterol 40: 414-420, 2005.

43 Ichikawa A, Arakawa F, Kiyasu J, Sato K, Miyoshi H, Niino D, Kimura Y, Takeuchi M, Yoshida $M$ and Ishibashi $Y$ : Methotrexate/iatrogenic lymphoproliferative disorders in rheumatoid arthritis: histology, Epstein-Barr virus, and clonality are important predictors of disease progression and regression. Eur J Haematol 91: 20-28, 2013.

44 Thonhofer R, Gaugg M, Kriessmayr M, Neumann $H$ and Erlacher L: Spontaneous remission of marginal zone B cell lymphoma in a patient with seropositive rheumatoid arthritis after discontinuation of infliximab-methotrexate treatment. Ann Rheum Dis 64: 1098-1099, 2005.

45 Chiu L, Choi P, Luk N, Chang M and Tang W: Spontaneous regression of primary cutaneous Epstein-Barr virus-positive, CD30-positive anaplastic large T-cell lymphoma in a hearttransplant recipient. Clin Exp Dermatol 34: e21-4, 2009.

46 Mohsin N, Budruddin M, Kamble P, Khalil M, Pakkyarra A, Jha A, Mohammed E, Ahmed H, Ahmed J and Thomas S: Complete regression of cutaneous B-cell lymphoma in a renal transplant patient after conversion from cyclosporin to sirolimus. Elsevier, pp. 1267-1271, 2007.

47 Baraboutis IG, Papastamopoulos V, Georgiou O, Skoutelis AT, Marinos L, Papadaki T, Rondogianni P, Apostolidis J, Lekakis LJ and Tsagalou EP: Long-term complete regression of nodal marginal zone lymphoma transformed into diffuse large B-cell 
lymphoma with highly active antiretroviral therapy alone in human immunodeficiency virus infection. Am J Med Sci 338: $517-521,2009$.

48 Iwatani T, Kawabata H, Miura D, Ota Y and Ohashi K: Complete spontaneous regression of primary diffuse large B-cell lymphoma of the breast. J Clin Oncol 29: e113-e115, 2010.

49 Kashiyama T, Tojima H, Mizozo A, Imahashi M, Yasuda J, Fujita A, Watanabe A, Suzuki A and Kimura H: [Diffuse large cell lymphoma with spontaneous regression in the lung and lymph nodes. Case report]. Nihon Kyobu Shikkan Gakkai Zasshi 30: 1175-1179, 1992.

50 Gattiker H, Wiltshaw E and Galton D: Spontaneous regression in non-Hodgkin's lymphoma. Cancer 45: 2627-2632, 1980.

51 Engel PA and Lee C: Sudden appearance and spontaneous regression of diffuse large $\mathrm{B}$ cell lymphoma in a man with a broken arm. BMJ Case Rep 2009, 2009. doi: 10.1136/ bcr.10.2008.1036
52 Zappasodi R, de Braud F and Di Nicola M: Lymphoma Immunotherapy: Current Status. Front Immunol 6: 448, 2015.

53 Riley DS, Barber MS, Kienle GS, Aronson JK, von SchoenAngerer T, Tugwell P, Kiene H, Helfand M, Altman DG, Sox H, Werthmann PG, Moher D, Rison RA, Shamseer L, Koch CA, Sun GH, Hanaway P, Sudak NL, Kaszkin-Bettag M, Carpenter JE and Gagnier JJ: CARE 2013 explanation and elaborations: reporting guidelines for case reports. J Clin Epidemiol 89: 218$235,2017$.
Received July 3, 2018

Revised July 23, 2018

Accepted July 24, 2018 